\title{
THE EFFECT OF PROFITABILITY AND LEVERAGE ON TAX AVOIDANCE WITH COMPANY SIZE AS A MODERATING VARIABLE \\ (Empirical Study on Property, Real Estate, and Building Construction Companies listed on the Indonesia Stock Exchange 2013-2018)
}

\author{
Anna Christin Silaban \\ Accounting Study Program, Faculty of Economics and Business, Universitas Mercu Buana, \\ Jakarta, Indonesia
}

Article DOI: https://doi.org/10.36713/epra5222

\begin{abstract}
The objectives of this study are as follows: 1) To examine the effect of Profitability on Tax Avoidance; 2) To examine the effect of Leverage on Tax Avoidance; 3) To assess the extent to which Company Size can moderate the relationship between Profitability and Tax Avoidance; and 4) To assess the extent to which Company Size can moderate the relationship between Leverage and Tax Avoidance. This type of research used in this research is casual associative research (causal associative research). The population in this study were property, real estate and building construction companies listed on the Indonesia Stock Exchange (BEI) during the period 20132018. The sample selection was using purposive sampling method. The analysis method used to test the hypothesis is Moderated Regression Analysis (MRA). The results showed that: 1) Profitability has no effect on tax avoidance in a negative direction; 2) Leverage affects tax avoidance in a positive direction; 3) Company size is unable to moderate the relationship between profitability and tax avoidance; and 4) Firm size is unable to moderate the relationship between leverage and tax avoidance.
\end{abstract}

KEYWORDS: Profitability, Leverage, Company Size, Tax Avoidance

\section{INTRODUCTION}

Tax is the biggest source of state revenue. The tax collected by the State functions as a source of funds intended for financing government expenditure and functions as a tool to regulate and implement policies in the social and economic fields and is used for the greatest prosperity of the people. Therefore, corporate and individual taxpayers are expected to be obedient in carrying out their tax obligations voluntarily and in compliance with tax regulations. Non-compliance of taxpayers can cause disruption of State finances. One way of disobedience is done by tax avoidance. Tax avoidance is an act of avoiding taxes, methods and techniques which are carried out by utilizing weaknesses in taxation provisions, so that they do not violate and oppose the applicable provisions (Pohan, 2017). Tax avoidance is not against the law, but in general all parties agree that tax avoidance is something that is practically unacceptable. This is because tax avoidance directly impacts the erosion of the tax base, which results in reduced tax revenue needed by the state (Cahyanti, et al., 2017)

In 2014, PT Toyota Manufacturing Indonesia practiced tax avoidance by exporting thousands of cars with export value less than the cost of sales. Meanwhile, the same product is sold in Indonesia at different prices. To export Toyota has a policy with its business unit in Singapore, Toyota Motor Asia Pacific Pte., Ltd, because Singapore has the lowest corporate tax rate in Southeast Asia. To reduce the amount of tax that must be paid in Indonesia, PT Toyota conducts transfer pricing beyond the reasonable business limits. The Ministry of Finance's Directorate General of Taxes has suspected TMMIN of using transactions between affiliated companies at home and abroad to avoid paying taxes by transfer pricing (Murwaningtyas, 2019). 


\section{SJIF Impact Factor: 7.001| ISI I.F.Value:1.241| Journal DOI: 10.36713/epra2016

There are several factors that are indicated to affect the Tax Avoidance action including profitability and leverage. This variable has indeed been taken a lot in several studies by previous researchers, but it still shows variations in research results or inconsistencies. Profitability is a measurement of a company's performance. Profitability of a company shows the ability of a company to generate profits for a certain period at a certain level of sales, assets and share capital. Profitability ratio aims as a measure of the level of effectiveness of management and can determine the ability of a company to earn profits for a certain period (Hery, 2016). The greater the profit, the greater the profitability of the company. Taxes are calculated based on profits owned by the company. The large amount of profits owned by the company, making the greater the amount of tax that must be paid by the company. The large amount of tax that must be paid will make the company do tax avoidance engineering.

In research conducted by Dewinta \& Setiawan (2016), Oktamawati (2017), Cahyanti, et al (2017) and Nengsih, et al (2018) which states that profitability affects tax avoidance. This statement is different from the results of research belonging to Permata, et al (2018), and Murwaningtyas (2019) which states that profitability has no significant effect on tax avoidance.

Leverage is a ratio used to measure the extent to which a company's assets are financed with debt (Fadila, 2017). That is, how much debt burden borne by the company compared to its assets. It is possible for a company to use debt to fulfill its operational and investment needs. However, debt will cause a fixed rate of return called interest. The interest expense borne by the company can be used as a deduction from the company's taxable income to reduce its tax burden. That way, the higher the value of the leverage ratio, means the higher the amount of funding from third party debt used by the company and the higher the interest costs arising from the debt. The higher interest costs will have the effect of reducing the company's tax burden. The greater the debt, the taxable profit will be smaller because the tax incentives for debt interest are greater (Darmawan \& Sukartha, 2014).

In a study conducted by Oktamawati (2017), Nugraha \& Mulyani (2019) which stated that leverage affects tax avoidance. The statement is different from the results of research by Dewinta \& Setiawan (2016), Cahyono, et al (2016), and Permata, et al (2018) which states that leverage does not have a significant effect on tax avoidance.

The inconsistencies of the results of previous studies encourage the author to add company size as a moderating variable in the relationship between profitability and tax avoidance, which later this moderating variable can strengthen or weaken the relationship between profitability and leverage with tax avoidance. Large companies tend to be able to produce stable profits, the ability to obtain a more stable profit tends to be owned by large companies compared to smaller companies. Large companies also tend to have good resources in managing their taxes. Large and stable profits coupled with owned resources will tend to companies avoid tax.

According to Ngadiman \& Puspitasari (2014), the size of the company as measured by total assets will affect the tax avoidance measures of the company, the greater the size of the company, making company managers tend to choose accounting methods that suspend reported earnings from the current period to the future period in order minimize reported profits. Large companies have more and more complex company operational activities so that there are gaps to be used in tax avoidance decisions. While small companies that have limited company operations and few will find it difficult to take tax avoidance measures because of the small gaps that can be exploited by companies in carrying out tax avoidance. In a study conducted by Dewinta \& Setiawan (2016), Oktamawati (2017) and Pratiwi (2019) who stated that company size influences tax avoidance. This statement is different from the results of research owned by Cahyono, et al (2016) and research by Nengsih, et al (2018) which states that company size has no effect on tax avoidance.

Researchers are motivated to conduct research on Property, Real Estate, and Building Construction Companies, because Property, Real Estate and Building Construction Companies play an important role in the field of economy and development in Indonesia. This sector is also one indicator to assess a country's economic development.

Based on the background description above, the authors are interested in conducting a study entitled: "The Effect of Profitability and Leverage Against Tax Avoidance with Company Size as a Moderating Variable (Empirical Study on Property, Real Estate, and Building Construction Companies listed on the Indonesia Stock Exchange 2013-2018) ".

Based on this background, this study aims 1) To examine the effect of profitability on tax avoidance; 2) To assess the effect of Leverage on Tax Avoidance; 3) To assess the extent to which Company Size can moderate the relationship between Profitability and Tax Avoidance; and 4) To assess the extent to which Company Size can moderate the relationship between Leverage and Tax Avoidance.

\section{LITERATURE REVIEW Agency Theory}

Jensen and Meckling (1976) state that an agency relationship is a contract between a manager (agent) and an investor (principal). There is a conflict of 


\section{SJIF Impact Factor: 7.001| ISI I.F.Value:1.241| Journal DOI: 10.36713/epra2016

interest between the owner and agent because the possibility of the agent acting is not in accordance with the interests of the principal, thereby triggering agency costs. Conflict in agency theory is usually caused by decision makers who do not participate in taking risks as a result of decision making mistakes. According to decision makers, the risk should be borne by the shareholders. This is what causes the asynchronous between the decision maker (manager) with the shareholders. Conflicts between shareholders and company management can be minimized in a way, managers must run the company in accordance with the interests of shareholders as well as in making decisions by managers must be adjusted to the interests of shareholders (Wahyuni, 2013).

\section{Stakeholders Theory}

According to Clarkson (1995) in Fauzan (2013), stakeholders are divided into two groups, namely primary and secondary. Primary stakeholders are groups of stakeholders who do not take part or participate in the operations of a company. Secondary stakeholders are groups of stakeholders who influence and are influenced by the company, but are not involved and are not so important for the survival of the company.

Stakeholder theory is a theory which states that a company is an entity that not only operates for its own interests, but must provide benefits to all its stakeholders, because the survival of a company is supported by stakeholders (Ghazali and Chariri, 2007). Shareholders, creditors, consumers, suppliers, the government, the public, analysts, and other parties are stakeholder groups that are considered by the company to disclose or not reveal information in the company's financial statements. All stakeholders have the right to obtain information about company activities.

\section{Legitimacy Theory}

According to Ahmad et al (2004) in Hasian (2017), the theory of legitimacy is based on the notion of a social contract that is implied between social institutions and society. Shocker and Sethi (1973 in Indra and Istianingsih, 2018) provide an explanation of the concept of social contracts as follows: All social institutions are no exception companies operate in society through explicit or implicit social contracts where their survival and growth are based on:

1) The final output (output) that can be given socially to the wider community.

2) Distribution of economic, social or political benefits to groups according to their power.

The legitimacy theory also explains that the practice of corporate responsibility disclosure must be carried out in such a way that the company's activities and performance are acceptable to the public. Ghozali and Chariri (2007) in Hasian (2017) explained that in order to legitimize company activities in the eyes of the public, companies tend to use environmentalbased performance and disclosure of environmental information.

Legitimacy theory is the theory most often used especially when it relates to social areas and environmental accounting. Although there is still a strong pessimism expressed by many researchers, this theory has been able to offer a real perspective on the voluntary recognition of a company by the public.

\section{Profitability}

Profitability is the main purpose of the establishment of the company. Profitability plays an important role for the company's future. Companies need to have good profitability for business continuity (Dari and Harnovinsah, 2017). Profitability is one indicator to assess the level of effectiveness of management performance in running a company by looking at the level of benefits obtained (Indracahya, et al, 2017). Profitability is measured by Return on Equity (ROE). ROE is a ratio that measures the level of net income obtained by the owner of the company for the invested capital or in other words measures the extent of the efficiency of the used capital itself. This ratio is also influenced by the size of the company's debt, if the proportion of debt is greater then this ratio will also be even greater. The formula is as follows:

$$
R O E=\frac{\text { Earning after } \text { Tax }}{\text { Shareholder's Equity }}
$$

\section{Leverage}

According to Fahmi (2014), leverage ratio is a measure of how much a company is financed with debt. The use of debt that is too high will endanger the company because the company will go into extreme leverage (extreme debt) that is the company is trapped in a high level of debt and it is difficult to release the debt burden. Therefore, the company must balance how much debt is worth taking and from which sources can be used to pay off debt. Leverage is measured by debt ratio (DR). This ratio measures how much the company's assets are financed by creditors. The higher the debt ratio (DR) the greater the amount of loan capital used in generating profits for the company. The formula is as follows:

\section{Company Size}

$$
\text { Debt Ratio }=\frac{\text { Total Liabilities }}{\text { Total Assets }}
$$

The size of the company is the size of the company, a large established company will have easy access to the capital market (Purnamasari \& Fitria, 2015). Large companies are given more attention by the public so they will be more careful in doing financial reporting, so that the impact of these companies is reporting conditions more accurately. 


\section{EPRA International Journal of Research and Development (IJRD)}

The size of the company will be symbolized by SIZE, and measured using the natural logarithm $(\ln )$ of the book value of total assets owned by the company.

\section{Tax Avoidance}

Tax avoidance is part of tax planning (tax planning) that is done legally by shrinking the tax object that is the basis for taxation that is still in accordance with the provisions of applicable tax laws. Legal strategies or methods in accordance with the provisions of the Act (Act), usually carried out by utilizing things that are ambiguous in the Act so that in this case the Taxpayer utilizes the gap caused by the ambiguity in the tax law. The tax saving strategy is also referred to as an aggressive tax strategy. Although tax avoidance has the potential to harm state revenue from the taxation sector, tax avoidance is a logical consequence that arises from every taxation policy issued by the Directorate General of Taxes. So that many companies try to find loopholes in the policy that are profitable for tax savings.

In this study, tax avoidance was measured using CETR (Cash Effective Tax Rate). CETR according to Dyreng, et. al (2010) is well used to describe corporate tax avoidance activities because CETR is not affected by changes in estimates such as valuation allowance or tax protection. In addition, measurements using CETR can answer the problems and limitations of tax avoidance measurement based on the GAAP ETR model. The smaller the CETR value, the greater the tax avoidance, and vice versa.

\section{Previous Research Review}

Previous research that can support this research is Dewinta \& Setiawan (2016) in his research entitled "Effect of Company Size, Company Age, Profitability, Leverage, and Sales Growth on Tax Avoidance". The results of his research show that the higher the size of the company, the age of the company, profitability, and sales growth will lead to increased tax avoidance. Leverage has no effect on tax avoidance. This means that the higher the leverage will not affect the increase in tax avoidance

Ginting (2016) in his research entitled "The Effect of Corporate Governance and Fiscal Loss Compensation on Tax Avoidance with Company Size as a Moderating Variable". The results showed that Institutional Ownership, and Fiscal Loss Compensation have a significant effect on Tax Avoidance, while Independent Commissioners have no significant effect on Tax Avoidance. Company size is not able to moderate (strengthen or weaken) the influence of Institutional Ownership, Independent Commissioners and Fiscal Loss Compensation for Tax Avoidance.

Permata, et al (2018) in his study entitled "Effect of Size, Age, Profitability, Leverage and Sales Growth on Tax Avoidance". The results of his research showed that company size, company age, profitability, leverage, and sales growth had no effect on tax avoidance.

Murwaningtyas (2019) in his study entitled "Factors Influencing Tax Avoidance" provides empirical evidence that corporate social responsibility, corporate age, fiscal loss compensation has a significant positive effect on tax avoidance, and profitability has no significant effect on tax avoidance.

\section{Theoretical Framework}

Based on the theoretical basis and some previous research, the framework in this study can be shown by the following picture:

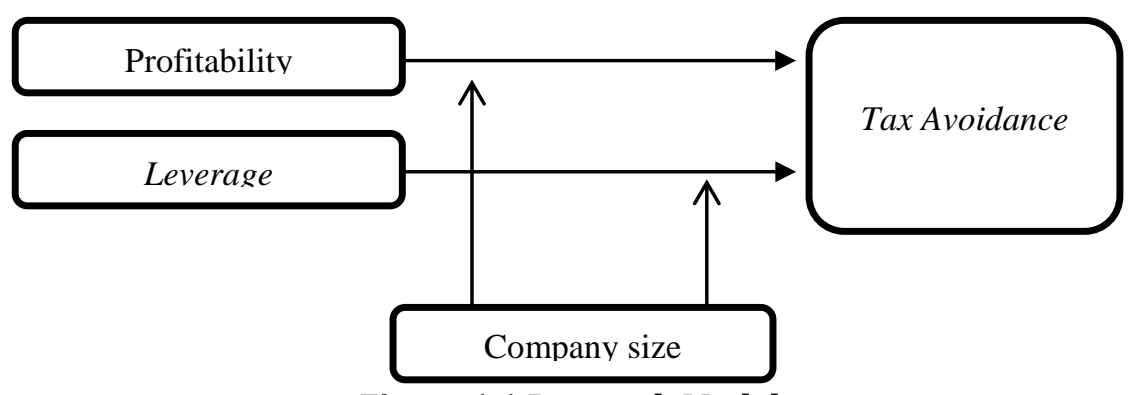

Figure 1.1 Research Model

\section{Research Hypothesis}

From the above thought framework, the researcher draws a hypothesis as follows:

Ha1 $=$ Profitability affects the Tax Avoidance

$\mathrm{Ha} 2=$ Leverage affects Tax Avoidance

Ha3 = Company size can moderate the relationship between profitability and tax avoidance
Ha4 = Company size can moderate the relationship between leverage and tax avoidance 


\section{EPRA International Journal of Research and Development (IJRD)}

\section{RESEARCH METHODOLOGY Types of research}

This type of research used in this study is a casual associative research (causal associative research). According to Sanusi (2011), associativecausal research is a research that seeks a relationship between two or more variables. The purpose of associative research is to look for relationships between one variable and another.

\section{Operational Definition and Variable Measurement}

The variables used in this study consisted of the dependent variable and the independent variable. Operational research variables can be summarized in table 1.1 .

Table 1.1 Operationalization of Variables

\begin{tabular}{|c|c|c|c|}
\hline Type Variable & Proxy & Rumus & Skala \\
\hline \multicolumn{4}{|l|}{ Dependent } \\
\hline Tax Avoidance & $\begin{array}{l}\text { CETR (Cash Effective Tax Rate) of the } \\
\text { company, that is cash spent on tax } \\
\text { costs divided by profit before tax. } \\
\text { Dyreng, et al (2010) }\end{array}$ & CETR & Rasio \\
\hline \multicolumn{4}{|l|}{ Independent } \\
\hline Profitability & $\begin{array}{l}\text { Return on Equity (ROE) is a ratio that } \\
\text { measures the level of net income } \\
\text { obtained by the owner of the company } \\
\text { for the invested capital or in other } \\
\text { words measures the extent of the level } \\
\text { of efficiency of own capital used. } \\
\text { (Ludijanto, 2011) }\end{array}$ & $\frac{\text { Earning after Tax }}{\text { Shareholder's Equity }}$ & Rasio \\
\hline Leverage & $\begin{array}{l}\text { Debt Ratio (DR) merupakan rasio yang } \\
\text { mengukur berapa besar aktiva } \\
\text { perusahaan yang dibiayai oleh } \\
\text { kreditur. (Ludijanto, 2011) }\end{array}$ & $\frac{\text { Total Liabilities }}{\text { Total Assets }}$ & Rasio \\
\hline \multicolumn{4}{|l|}{ Moderating } \\
\hline Company Size & $\begin{array}{l}\text { Large-scale small companies, an } \\
\text { established large company will have } \\
\text { easy access to the capital market } \\
\text { (Purnamasari \& Fitria, 2015) }\end{array}$ & $\begin{array}{c}\text { Logaritma Natural Total } \\
\text { Aset }\end{array}$ & Rasio \\
\hline
\end{tabular}

\section{Data Types and Sources}

The data used in conducting this research is secondary data, namely data obtained through intermediaries from second parties or certain media that support this research. The data used in this study is secondary data in the form of financial statements of property, real estate and building construction companies listed on the IDX during 2013-2018 which are obtained from the Indonesia Stock Exchange website (www.idx.co.id)..

\section{Population and Research Samples}

The population in this study were property, real estate and building construction companies listed on the Indonesia Stock Exchange (IDX) during the period 2013-2018. The sample is a part of the population that is used to estimate the characteristics of the population. The sampling technique is using purposive sampling technique. According to Widyani (2010), the purosive sampling method is the selection of samples based on the suitability of the sample characteristics with the predetermined sample selection criteria. The sample criteria used in this study are:

1. Property, Real Estate and Building Construction Companies listed on the Indonesia Stock Exchange (IDX) in the period 2013-2018.

2. Publish audited financial statements for the period 2013-2018

3. The company did not experience a loss during the study year.

4. Data owned by the company are complete and in accordance with the variables studied.

According to the criteria above, the number of samples used were 13 companies during the 6 periods namely 2013, 2014, 2015, 2016, and 2018. Then the number of samples obtained was 13 companies $\times 6$ periods $=78$ data to be used in this study.

\section{Data collection technique}

Data collection methods in this research are literature study and documentation methods. Literature study method by studying literature and 


\section{EPRA International Journal of Research and Development (IJRD)}

Volume: 5 | Issue: 9 | September 2020

reviewing a variety of literature literature such as various journals, articles and other literature books that support the research process. While the documentation method is the process of collecting data by recording documents related to this research.

\section{Analysis Method \\ Descriptive statistics}

Descriptive statistics in this study are used to provide a description of the character of the research variable using a frequency distribution table that shows the mode number, the range of scores and the standard of division

\section{Classic assumption test}

This research was conducted with a simple regression analysis. The use of simple regression analysis must be free from testing classic assumptions. For this reason, before a simple regression analysis is required, classical assumptions must be tested first. Testing classic assumptions is done using normality test, multicollinearity test, heterokedasticity test and autocorrelation test.

\section{Hypothesis testing}

In this study the authors used three independent variables, one dependent variable and one moderating variable. The analytical method used to test hypotheses is the interaction test or often referred to as Moderated Regression Analysis (MRA), which is a special application of linear multiple regression where the regression equation contains interaction elements (multiplication of two or more independent variables) (Ghozali, 2011). The regression equation is as follows:

$$
\begin{aligned}
Y= & \alpha+\beta_{1} X_{1}+\beta_{2} X_{2}+\varepsilon \\
Y= & \alpha+\beta_{1} X_{1}+\beta_{2} X_{2}+\beta_{3} Z+\varepsilon \\
Y= & \alpha+\beta_{1} X_{1}+\beta_{2} X_{2}+\beta_{3} Z+\beta_{4} X_{1} * Z+\beta_{5} X_{2} * Z \\
& +\varepsilon
\end{aligned}
$$

Dimana :

$$
\begin{aligned}
\mathrm{Y}= & \text { Tax Avoidance } \\
\mathbf{\alpha}= & \text { konstanta } \\
\beta= & \text { number or direction of the regression } \\
& \text { coefficient, which shows the number of } \\
& \text { increase or decrease in the dependent } \\
& \text { variable based on the independent variable } \\
\mathrm{X}_{1}= & \text { Profitability } \\
\mathrm{X}_{2}= & \text { Leverage } \\
\mathrm{Z}= & \text { Company size } \\
\varepsilon= & \text { error }
\end{aligned}
$$

In this study the significance level ( $\alpha$ ) of 0.05 or $5 \%$ was used. This multiple regression analysis was carried out with the help of the SPSS (Statistical Package For Social Sciences) Release 25.0 for Windows program so that the coefficient of determination, the statistical $F$ value and the statistical $t$ value used in hypothesis testing can be obtained.

\section{RESEARCH RESULTS AND DISCUSSION Research Data Description}

Descriptive statistical results about the research variables are presented in table 1.2. From this table we can find information about the average, maximum value, minimum value and standard deviation.

Table 1.2 Descriptive Statistics Results

\begin{tabular}{|l|c|c|c|c|}
\hline \multicolumn{1}{|c|}{ Variabel } & Min & Max & Mean & $\begin{array}{c}\text { Std. } \\
\text { Deviation }\end{array}$ \\
\hline Profitability & 78 & 0,01 & 0,31 & 0,13 \\
\hline Leverage & 78 & 0,22 & 0,84 & 0,56 \\
\hline Company size & 78 & 28,84 & 32,45 & 30,58 \\
\hline Tax Avoidance & 78 & 0,00 & 0,49 & 0,15 \\
\hline Source: Data processed (2020)
\end{tabular}

Based on table 1.2 above, it can be presented descriptive statistical results about the following research variables: The average profitability value measured by Return on Equity (ROE) of 0.13 or $13 \%$, with a standard deviation of 0.070 or $7 \%$, which means small data variations (less than $6 \%$ of the mean). ROE ranges from the lowest value of 0.01 (1\%), namely Sentul City Tbk company in 2014 to the highest value of 0.31 (31\%), namely the Pakuwon Jati Tbk company in 2014. The average ROE value of 0.13 This shows that for every IDR 1 fund invested by investors as share capital, it will generate a net profit of $13 \%$.
The average value of leverage as measured by Debt Ratio (DR) is 0.56 or $56 \%$ with a standard deviation value of 0.155 or $15.5 \%$, which means that the data variation is small (less than $40.5 \%$ of the mean). DR ranges from the lowest value of 0.22 (22\%), namely Bekasi Fajar Industrial Estate company in 2014 to the highest value of 0.84 (84\%), namely the Adhi Karya (Persero) Tbk company in 2014. The average DR value is The 0.56 shows that the large assets of companies financed by creditors amounted to $56 \%$.

The average value of company size measured by the natural logarithm of total assets is 30.58 trillion with a standard deviation value of 0.749 


\section{EPRA International Journal of Research and Development (IJRD)}

Volume: 5 | Issue: 9 | September 2020

trillion, which means small data variations (less than 29.83 trillion of the mean). The size of the company ranges from the lowest value of 28.84 trillion, namely the Bekasi Fajar Industrial Estate company in 2013 to the highest value of 32.45 trillion, namely the Waskita Karya (Persero) Tbk company in 2018. The average value of the company size of 30.58 shows that the average sample company has an asset stability of 30.58 trillion.

The average value of Tax Avoidance measured by CETR (Cash Effective Tax Rate) of 0.15 or $15 \%$ with a standard deviation of 0.145 or $14.5 \%$, which means that the variation of the data is very small (less than $0.5 \%$ of the mean). CETR ranges from the lowest value of 0.00 or $0 \%$, namely the company Indal Sentul City Tbk in 2016 to the highest value of
0.49 or $49 \%$, namely the Adhi Karya (Persero) Tbk company in 2016. The average CETR value is 0,15 shows that the company issued cash for tax payments on average by $15 \%$ of the total pre-tax profit on the sample company.

\section{Classic assumption test Normality test}

Testing for normality using the Lilliefors test. Provisions in the error test are if the statistic L count $<\mathrm{L}$ table $(\alpha=0.05)$, then the error data is normally distributed. But if $\mathrm{L}$ count $>\mathrm{L}$ table $(\alpha=0.05)$, then the data is not normally distributed. The results of the calculation are as follows:

Table 1.3 Summary of the Normality Test

\begin{tabular}{|c|c|c|c|c|c|c|}
\hline \multirow{2}{*}{ No } & \multirow{2}{*}{ Taksiran } & \multirow{2}{*}{$\mathbf{n}$} & \multirow{2}{*}{ L Count } & \multicolumn{2}{|c|}{$\mathbf{L}_{\text {Tabel }}$} & \multirow{2}{*}{ Keputusan } \\
\cline { 5 - 6 } & & & $\mathbf{\alpha = 0 , 0 5}$ & $\boldsymbol{\alpha}=\mathbf{0 . 0 1}$ & \\
\hline 1 & Y atas X1 & 78 & 0,0160 & 0,1003 & 0,1167 & Normal \\
\hline 2 & Y atas X2 & 78 & $-0,1048$ & 0,1003 & 0,1167 & Normal \\
\hline 3 & Y atas X3 & 78 & 0,0269 & 0,1003 & 0,1167 & Normal \\
\hline
\end{tabular}

\section{Multicollinearity Test}

The results of the tolerance tolerance according to table 1.4 show that there are no independent variables that have a tolerance value of less than $10 \%$; all tolerance values are more than $10 \%$; which means there is no correlation between variables. The results of the calculation of the value of the variance inflation factor (VIF) also show the same thing, there are no independent variables that have a VIF value of more than 10; the value of the variance inflation factor (VIF) are all less than 10. The conclusion is that there is no multicollinearity between the independent variables in the regression model based on the tolerance value test.

Table 1.4 Multicollinearity Test Results

\begin{tabular}{|l|c|c|}
\hline \multirow{2}{*}{ Variabel } & \multicolumn{2}{|c|}{ Collinearity Statistics } \\
\cline { 2 - 3 } & Tolerance & VIF \\
\hline Profitability & 0,868 & 1,153 \\
\hline Leverage & 0,819 & 1,220 \\
\hline Company size & 0,815 & 1,228 \\
\hline
\end{tabular}

Source: Data processed (2020)

\section{Autocorrelation Test}

Autocorrelation test is used to determine whether there is a correlation between a fault in a certain period with a mistake in the previous period. A good regression model is a regression that is free from autocorrelation. Autocorrelation test can be done by testing the Durbin-Watson (DW). The results of the autocorrelation test can be seen in the following table:

Table 1.5 Autocorrelation test results

\begin{tabular}{|c|c|c|c|c|c|}
\hline Model & R & R Square & $\begin{array}{c}\text { Adjusted R } \\
\text { Square }\end{array}$ & $\begin{array}{c}\text { Std. Error of } \\
\text { the Estimate }\end{array}$ & Durbin-Watson \\
\hline 1 & $0,658^{\mathrm{a}}$ & 0,433 & 0,410 & 0,112 & 1,815 \\
\hline
\end{tabular}

Based on SPSS output, the Durbin Watson statistical value of 1,810 is obtained. While from the Durbin Watson table with $\mathrm{n}=78$ and $\mathrm{k}=3$, we get $\mathrm{d}$ tables, namely $\mathrm{dl}$ (outer boundary) $=1.554$ and $\mathrm{du}$ (inner limit) $=1.713$ with a significance level of $5 \%$, 4-du $=2,287$; and 4-dl $=2,447$; then from the account it is concluded that the DW-test is located in the test area. Referring to Ghozali (2011), the regression model in this study is free from the autocorrelation 


\section{EPRA International Journal of Research and Development (IJRD)}

Volume: 5 | Issue: 9 | September 2020

- Peer Reviewed Journal

problem because the Durbin Watson values are between du and 4 du.

\section{Heteroscedasticity Test}

Detection of heterokedastisitas are: 1) Probability value $>0.05$ means free from heterokedastisitas. 2) Probability value $<0.05$ means it is exposed to heterokedasticity. The results of testing using the Spearman rank test can be seen in the following table:

Table 1.6 Heteroscedasticity Test Results

\begin{tabular}{|l|l|l|c|c|c|}
\hline \multicolumn{2}{|c|}{} & X1 & X2 & X3 \\
\hline Spearman's rho & Abres & $\begin{array}{l}\text { Correlation } \\
\text { Coefficient }\end{array}$ & $-0,261^{*}$ & $0,251^{*}$ & $-0,070$ \\
\cline { 3 - 6 } & & Sig. (2-tailed) & 0,071 & 0,090 & 0,544 \\
\cline { 3 - 6 } & $\mathrm{N}$ & 78 & 78 & 78 \\
\hline
\end{tabular}

Source: Data processed (2020)

Spearman rank test results in the table above shows the significance value of each variable of $0.071,0.090$, and 0.544 . Because the significance value of each variable is greater than 0.05 , it can be concluded that the data are free from heterocedasticity.

\section{Interaction Test}

Interaction test or often called Moderated Regression Analysis (MRA) is a special application of linear multiple regression where the regression equation contains interaction elements (multiplication of two or more independent variables) (Ghozali, 2011). Analysis with this interaction test was carried out with the help of the SPSS (Statistical Package for Social Sciences) Release 25.0 for Windows program. From the data processing through the SPSS program the following results are obtained:

Table 1.7 Results of moderating variable regression analysis

\begin{tabular}{|c|c|c|c|c|c|c|c|}
\hline Information & B & $t$ tabel & $\mathbf{t}$ count & Sig & Adj $R^{2}$ & F $_{\text {Count }}$ & Sig \\
\hline \multicolumn{8}{|l|}{ Equation 1} \\
\hline (Constant) & $-0,161$ & & & & \multirow{3}{*}{0.343} & \multirow{3}{*}{21,060} & \multirow{3}{*}{0.000} \\
\hline $\mathrm{X} 1$ & $-0,014$ & 1.665 & $-0,073$ & 0,942 & & & \\
\hline $\mathrm{X} 2$ & 0,565 & 1.665 & 6,366 & 0,000 & & & \\
\hline \multicolumn{8}{|l|}{ Equation 2} \\
\hline (Constant) & 1,490 & & & & \multirow{6}{*}{0.422} & \multirow{6}{*}{12,245} & \multirow{6}{*}{0.000} \\
\hline $\mathrm{X} 1$ & 7,572 & 1.665 & 1,637 & 0,106 & & & \\
\hline $\mathrm{X} 2$ & $-3,736$ & 1.665 & $-0,839$ & 0,404 & & & \\
\hline $\mathrm{X3}$ & $-0,056$ & 1.665 & $-2,939$ & 0,004 & & & \\
\hline $\mathrm{X} 1 \mathrm{X} 3$ & $-0,259$ & 1.665 & $-1,677$ & 0,098 & & & \\
\hline $\mathrm{X} 2 \mathrm{X} 3$ & 0,148 & 1.665 & 0,997 & 0,322 & & & \\
\hline
\end{tabular}

Based on the results of the regression tests above, an equation can be formed as follows:

$\mathrm{Y}=-0,161-0,014 \mathrm{X}_{1}+0,565 \mathrm{X}_{2}+\mathrm{e}$

$Y=1,490+7,572 X_{1}-3,736 X_{2}-0,056 X_{3}-0,259 X_{1} X_{3}+0,148 X_{2} X_{3}+e$

From table 1.7 it is known that the adjusted $\mathrm{R}$ square value in equation 1 is 0.343 . This means that $34.3 \%$ of tax avoidance can be influenced by profitability and leverage, the remaining $65.7 \%$ $(100 \%-34.3 \%)$ is explained by other causes outside the model. While the adjusted $\mathrm{R}$ square value in equation 2 is 0.422 . This means that $42.2 \%$ of tax avoidance can be influenced by profitability, leverage, company size, $\mathrm{X}_{1} \mathrm{X}_{3}$ and $\mathrm{X}_{2} \mathrm{X}_{3}$ the remaining $57.8 \%(100 \%-42.2 \%)$ is explained by other causes outside the model.

From the Anova test or the $\mathrm{F}$ test in table 1.7 above, the F Count value in equation 1 is 21,060 with a significance probability that indicates 0,000 . Test probability values are much smaller than $\alpha=0.05$. This shows that together (simultaneously) tax avoidance can be influenced by profitability and leverage variables. While the value of the F Count in Equation 2 is 12.245 with a probability probability of 


\section{EPRA International Journal of Research and Development (IJRD)}

0.000 . Test probability values are much smaller than $\alpha=0.05$. This shows that together (simultaneously) tax avoidance can be influenced by profitability, leverage, company size, $\mathrm{X}_{1} \mathrm{X}_{3}$ and $\mathrm{X}_{2} \mathrm{X}_{3}$ variables.

\section{Hypothesis test \\ Effect of profitability on tax avoidance}

Based on theount results in table 1.7 above, it can be seen that the table is greater than tcount, with a value of t table 1.665 and tcount -0.073 and the significance level is greater than 0.05 . This means that profitability has an insignificant negative effect on tax avoidance because of its negative direction. Thus Hal was rejected.

\section{Effect of Leverage on tax avoidance}

Based on theount results in table 1.7 above, it can be seen that the ttable is smaller than tcount, with a ttable value of 1.665 and tcount 6.366 and the level of significance is much smaller than 0.05 . This means that leverage has a positive effect on tax avoidance because of its positive direction. Thus $\mathrm{Ha} 2$ received.

\section{Company size can moderate the relationship between profitability and tax avoidance}

Based on theount results in table 1.7 above, it can be seen that the tcount $X_{1} X_{3}$ (moderator) value is greater than ttable, with tcount value -1,677 and ttable 1,665 and the significance level is greater than 0.05 . This means that company size cannot moderate the relationship between profitability and tax avoidance. Thus Ha3 was rejected.

\section{Company size can moderate the relationship between leverage and tax avoidance}

Based on the account results in table 1.7 above, it can be seen that the tcount $\mathrm{X}_{2} \mathrm{X}_{3}$ (moderator) value is smaller than ttable, with tcount value of 0.997 and ttable 1.665 and the significance level is greater than 0.05 . This means that company size cannot moderate the relationship between leverage and tax avoidance. Thus Ha4 was rejected.

\section{DISCUSSION}

\section{Effect of Profitability on Tax Avoidance}

From the results of the study note that profitability as measured by return on equity (ROE) has no effect on tax avoidance with a negative direction. This means that the lower or higher profitability of the company does not affect the high or low tax avoidance. Profitability has no effect on tax avoidance because a company that has high ROE means being able to carry out its operations efficiently and by the government this will be rewarded by providing a lower effective tax rate compared to companies that operate less efficiently (tax subsidy). In other words, companies that have high ROE will be obliged to pay higher taxes so that company management has a tendency to take tax avoidance measures, even reducing the possibility of tax evasion.

In addition, the higher the profitability, the lower the tax avoidance company means the company can pay taxes according to regulations, high-income companies so to issue or pay taxes there is no problem because it has sufficient cash flow to pay taxes. So, companies do not have to hide to avoid tax avoidance, the sample used by public companies means that every manager's actions can be monitored by shareholders and shareholders are happy with high profits so that the price of share earnings is high. There may be efforts by managers to avoid taxes that can damage the reputation of the company if the tax authorities find out, if the reputation decreases the share price will also decrease. So companies do not avoid taxes even though high profitability.

The results of this study are in line with the results of research conducted by Permata, et al (2018), and Murwaningtyas (2019) which states that profitability has no significant effect on tax avoidance. However, the results of this study contradict the results of research conducted by Dewinta \& Setiawan (2016), Oktamawati (2017), Cahyanti, et al (2017) and Nengsih, et al (2018) which states that profitability has an effect on tax avoidance.

\section{Effect of leverage on tax avoidance}

The leverage variable influences tax avoidance in a positive direction. This means that the higher the leverage, the higher the tax avoidance action. Leverage has a positive effect on tax avoidance because debt that results in the emergence of interest expense can be a deduction from taxable profits, while dividends derived from retained earnings cannot be a deduction from profit. Interest expense that can be used as a deduction for taxable profit is the interest expense arising from loans to third parties or creditors who have no relationship with the company (Oktamawati, 2017).

The results of this study are in line with the results of research conducted by Oktamawati (2017), Nugraha \& Mulyani (2019), which states that leverage affects tax avoidance. However, the results of this study contradict the results of research conducted by Dewinta \& Setiawan (2016), Cahyono, et al (2016), and Permata, et al (2018) which states that leverage does not have a significant effect on tax avoidance. 


\section{EPRA International Journal of Research and Development (IJRD)}

Volume: 5 | Issue: 9 | September 2020

- Peer Reviewed Journal

\section{Company size can moderate the relationship between profitability and tax avoidance}

The results showed that company size was not able to moderate the relationship between profitability and tax avoidance. This means that tax avoidance can be done either by large companies or small companies that have high profitability. Profitability measured by using return on assets shows the company's ability to manage its assets to generate profits. The greater the acquisition of the value of the company's ROA, the higher the profit generated by the company. So if the company's profits are high, the tax burden will also be high along with the increase in corporate profits, so it is very possible the company is trying to avoid increasing the tax burden imposed.

The results of this study do not support the findings of Putra \& Jati (2018) which states that the interaction between profitability and company size will cause the level of tax avoidance by companies to decline.

\section{Company size can moderate the relationship between leverage and tax avoidance}

The results showed that company size was not able to moderate the relationship between leverage and tax avoidance. This is because companies that are classified as large companies tend not to practice tax avoidance by avoiding audits from the tax office, audits can cause the amount of tax paid to be more and have a big influence on the company's cash flow and profitability.

The results of this study support the findings of Hutapea \& Herawaty (2020) which states that company size is not able to moderate the relationship between leverage and tax avoidance.

\section{Conclusion}

Based on the results of the analysis conclusions can be drawn as follows: 1) Profitability does not affect the tax avoidance with a negative direction; 2) Leverage affects the tax avoidance in a positive direction; 3) Company size is not able to moderate the relationship between profitability and tax avoidance; and 4) Company size is not able to moderate the relationship between leverage and tax avoidance.

\section{Limitation}

There are several limitations found in this study, among others: 1) Limited research using independent variables, namely the Profitability variable, Leverage; 2) Researchers limit the object of research to Property, Real Estate and Building Construction Companies listed on the Indonesia Stock Exchange.

\section{Suggestions}

By considering existing limitations, it is hoped that future research will improve the following factors: 1) For companies to be able to pay attention to any decisions that will be made and the risks that will be borne from any decisions made whether they are in accordance with the law and applicable tax regulations. Judging from the average size of the company which tends to be closer to the maximum value, which causes companies to tend to be more supervised by the government in terms of tax revenue; 2) The government is expected to increase more thorough supervision of the taxes paid by companies so as to increase state tax revenue and reduce tax avoidance practices by companies; 3 ) Further researchers may add research objects not only property, real estate, and building construction companies listed on the Indonesia Stock Exchange (IDX); and 4) For academics, the results of this study can be used as a rationale for developing research in the field of accounting, especially those related to tax avoidance.

\section{REFERENCE}

A. Kadim \& Nardi Sunardi. (2019). Pengaruh Profitabilitas, Ukuran Perusahaan Terhadap Leverage Implikasi Terhadap Nilai Perusahaan Cosmetics and Household yang terdaftar di Bursa Efek Indonesia. Jurnal Sekuritas. Vol. 3, No. 1, September

1. Agus Sartono. (2010). Manajemen Keuangan Teori dan Aplikasi. Yogyakarta: BPFE.

2. Amanda Dhinari Permata, Siti Nurlaela, dan Endang Masitoh W. (2018). Pengaruh Size, Age, Profitability, Leverage dan Sales Growth Terhadap Tax Avoidance. Jurnal Akuntansi dan Pajak. Vol. 19, No. 01

3. Chairil Anwar Pohan. (2017). Manajemen Perpajakan: Strategi Perencanaan Pajak \& Bisnis (Edisi Revisi). Jakarta: Gramedia Pustaka Utama

4. Deddy Dias Cahyono, Rita Andini dan Kharis Raharjo. (2016). Pengaruh Komite Audit, Kepemilikan Institusional, Dewan Komisaris, Ukuran Perusahaan, Leverage (DER) dan Profitabilitas (ROA) terhadap tindakan Tax avoidance. Jurnal Of Accounting. Vo. 2, No. 2, Maret

5. Diah Ayu Purnamasari dan Astri Fitria. 2015. Pengaruh Perputaran Piutang dan Ukuran Perusahaan Terhadap Profitabilitas Perusahaan Kimia. Jurnal Ilmu dan Riset Akuntansi. Vol. 4, No. 8

6. Faisal Riza. (2018). Pengaruh Corporate Governance, Likuiditas dan Kinerja Keuangan Terhadap Nilai Pasar Perusahaan (Studi Empiris Emiten Yang Mendapat GCG award IICD Tahun 2010-2012). Jurnal Profita. Vol. 11. No. 1. April

7. Giawan Nur Fitria. (2018). Pengaruh Kepemilikan Institusional, Komisaris Independen, Karakter Eksekutif dan Size Terhadap Tax 


\section{EPRA International Journal of Research and Development (IJRD)}

Avoidance (Study Empiris Pada Emiten Sektor Perdagangan yang Terdaftar di BEI Tahun 20142017). Profita: Komunikasi Ilmiah Akuntansi dan Perpajakan. Vol. 11 No. 3 Desember

8. Hanna Pratiwi. (2019). Pengaruh Ukuran Perusahaan, Kualitas Audit Dan Komite Audit Terhadap Tax Avoidance Dengan Debt Equity Ratio Sebagai Variabel Kontrol. Jurnal EKOBISTEK. Vol. 8, No. 2, Oktober

9. Hery. (2016). Analisis Laporan Keuangan. Bandung: Grasindo

10. Hestia Nengsih, Elly Suryani dan Kurnia. (2018). Pengaruh Karakter Eksekutif, Profitabilitas Dan Ukuran Perusahaan Terhadap Tax Avoidance (Studi Pada Perusahaan Manufaktur Subsektor Consumer Goods yang Terdaftar di Bursa Efek Indonesia Tahun 2012-2016). e-Proceeding of Management. Vol. 5, No. 3, Desember

11. Ida Ayu Rosa Dewinta dan Putu Ery Setiawan. (2016). Pengaruh Ukuran Perusahaan, Umur Perusahaan, Profitabilitas, Leverage, dan Pertumbuhan Penjualan terhadap Tax Avoidance. E-Jurnal Akuntansi Universitas Udayana. Vol. 14, No. 3, Maret

12. Imam Ghozali. (2013). Aplikasi Analisis Multivariate dengan Program IBM SPSS 22. Semarang: Badan Penerbit Universitas Diponegoro.

13. I Gede Hendy Darmawan dan I Made Sukartha. (2014). Pengaruh Penerapan Corporate Governance, Leverage, Return On Assets dan Ukuran Perusahaan pada Penghindaran Pajak. E-Jurnal Akuntansi Universitas Udayana. Vol. 9, No. 1

14. Irni Sri Cahyanti, Muhsin, dan Bambang Suharto. (2017). Profitabilitas, Leverage, Likuiditas, dan Tax Avoidance Perusahaan Pertambangan yang Terdaftar di Jakarta Islamic Index. Jurnal Ekubis. Volume 2, No. 1, September

15. Kadek Irrine Devita Angelina dan I Ketut Mustanda. (2016). Pengaruh Ukuran Perusahaan, Pertumbuhan Penjualan dan Profitabilitas Pada Struktur Modal Perusahaan. E-Jurnal Manajemen Unud. Vol. 5, No. 3

16. Lim, YD. (2011). Tax avoidance, cost of debt and shareholder activism: Evidence from Korea. Journal of Banking \& Finance 35, 456-470.

17. Mayarisa Oktamawati. (2017). Pengaruh Karakter Ekekutif, Komite Audit Ukuran Perusahaan, Leverage, Pertumbuhan Penjualan dan Profitabilitas terhadap Tax Avoidance. Jurnal Akuntansi Bisnis. Vol. XV, No. 30, Maret

18. Melisa Fadila. (2017). Pengaruh Return On Asset, Leverage, Ukuran Perusahaan Kompensasi Rugi Fiskal, Kepemilikan Institusional, dan Koneksi Politik Terhadap Penghindaran Pajak (Studi Empiris pada Perusahaan Manufaktur yang Terdaftar di BEI Tahun 2011-2015). JOM Fekon. Vol. 4, No.1, Februari

19. Moehammad Iman Nugraha dan Susi Dwi Mulyani. (2019). Peran Leverage sebagai Pemediasi Pengaruh Karakter Eksekutif, Kompensasi Eksekutif, Capital Intensity, dan
Sales Growth Terhadap Tax Avoidance. Jurnal Akuntansi Trisakti. Vol. 6, No. 2 September

20. Munawir. (2010). Analisa Laporan Keuangan. Edisi keempat. Yogyakarta: Liberty

21. Nanda Eka Murwaningtyas. (2019). FaktorFaktor Yang Memengaruhi Penghindaran Pajak. JASa (Jurnal Akuntansi, Audit dan Sistem Informasi Akuntansi). Vol. 3, No. 1, April

22. Ngadiman dan Christiany Puspitasari. (2014). Pengaruh Leverage, Kepemilikan Institusional, dan Ukuran Perusahaan Terhadap Penghindaran Pajak (Tax Avoidance) Pada Perusahaan Sektor Manufaktur Yang Terdaftar di Bursa Efek Indonesia 2010-2012. Jurnal Akuntansi. Volume XVIII, No. 03, September

23. Rista Bintara. (2019). Analisis Pengaruh Ukuran Perusahaan dan Mekanisme Corporate Governance Terhadap Manajemen Laba (Studi Empiris Pada Perusahaan Manufaktur Sub Sektor Logam \& Sejenisnya yang Terdaftar di Bursa Efek Indonesia Tahun 2011-2014). Profita: Komunikasi Ilmiah Akuntansi dan Perpajakan. Volume 12 Nomor 1, April

24. Rista Bintara dan Putri Renalita Sutra Tanjung. (2019). Analysis of Fundamental Factors on Stock Return. International Journal of Academic Research in Accounting, Finance and Management Sciences. Vol. 9, No. 2

25. Scott D. Dyreng, Michelle Hanlon and Edward L. Maydew. (2008). Long-Run Corporate Tax Avoidance. The Accounting Review. Vol. 83, No. 1 